\title{
DESIGN AND MANUFACTURE OF EMBRYOLOGICAL MODELS FOR DIDACTIC USE
}

\author{
PROJETO E FABRICAÇÃO DE MODELOS EMBRIOLÓGICOS PARA USO \\ DIDÁTICO
}

\begin{abstract}
Henrique Nunes Pereira OLIVA ${ }^{1}$; Ramon Nogueira DIAS ${ }^{2}$; Humberto Gabriel RODRIGUES ${ }^{3}$
1. Professor of Mechanical Engineering major at Centro Universitário FIPMoc (UNIFIPMoc) and medical student at UNIFIPMoc, Montes Claros, MG, Brazil. hnpo@ hotmail.com; 2. Student of Mechanical Engineering major at Centro Universitário FIPMoc (UNIFIPMoc), Montes Claros, MG, Brazil; 3. Biologist. PhD in Health Sciences from the University of Brasília (UNB). Professor of Medicine at Centro Universitário FIPMoc (UNIFIPMoc) and at State University of Montes Claros (UNIMONTES), Montes Claros, MG, Brazil.
\end{abstract}

\begin{abstract}
Some areas of knowledge are usually related to a high degree of abstraction involved in the object studied. In the case of the embryology study, for instance, the students' learning difficulties are recurrent due to a lack of didactic resources, which may aid the interpretation process of the figures presented in related literature. Based on the motivation to improve university education, specially in the area of biological sciences, the present work aims to represent in three dimensions, stages of the human embryological development. SolidWorks 3D modeling software was used, as well as didactic material related to the subject of embryology, conception and human development, such as books, atlases and scientific papers. There were designed, in 3D software, models representing the stages of human embryonic development. This means of production allowed the elaboration of exclusive anatomic models, with low cost (less than $\mathrm{R} \$ 100,00$ for more than 10 parts) and ease of visual interpretation. The models were designed in scale, such that it was possible to compare models that represent distinct periods of ontogenic development. It was possible to contribute to an improvement in the understanding of the topic of embryology for students with major related to health, through the visualization, in three dimensions, of models that are sometimes very expensive as physical pieces, or even nonexistent in market.
\end{abstract}

KEYWORDS: Embryology. 3D Printing. Teaching. Education. Computer Aided Design.

\section{INTRODUCTION}

Some areas of knowledge are generally related to a high degree of abstraction involved in the object studied. In the case of the embryology study, for example, the students' learning difficulties are recurrent, due to a lack of didactic resources, which may aid in the interpretation process of the figures presented in related literature. The difficulty occurs due to the impossibility to visualize in scale or real time, the processes of ontogenic development. This impossibility is aggravated by the scarcity of didactic material, related to threedimensional models of such elements (FREITAS et al., 2008).

The creativity, combined with the update, through the knowledge of modern resources, allows the improvement of teaching (SOUZA et al., 2007). For the subject of human embryology, the prospects of improving their learning are immense, considering the new technologies that can contribute to their study. The motivation for this is special, given that, according to Perotta et al. (2004), it has been a complex subject, mainly due to the need to interpret morphogenesis in a three-dimensional way. The teaching technique most used in higher schools, and even considered by some as the only possible for such a level of education, is the expositive (SOUZA et al., 2007). This technique, without the contribution of a practical element, such as the possibility of manipulation of a three-dimensional model, may leave something to be desired regarding the teaching of embryology.

Previous work, such as that of Freitas et al. (2008), have worked in the construction of embryological models with recyclable material, of low cost, aiding the process of teaching and learning in the scope of the embryology. In view of the idea proposed by the work of Freitas et al. (2008), in its time, it is possible to consider ways to continue the innovation presented. In addition, in order to seek and allow greater ease and standardization in the making of embryological models it can be considered manufacturing the models with the rapid prototyping method (RP).

Grimm (2004) mentions that the RP method can consist of four strands, namely: Stereolithography (SLA), Selective laser sintering (SLS), Modeling by 
fusion and deposition and Three-dimensional printing (3D printing). SLA is how the device responsible for working with this technology is called. The SLA uses a laser, capable of polymerizing a resin and making it solid, thus creating the final piece. According to Gorni (2001), SLS technique was patented in 1989 and, like Stereolithography, uses laser. Modeling by fusion and deposition consists of the deposition of molten thermoplastic resin, by means of an injector, until formation of the final part. 3D printing was developed and patented in the early 1990's at the Massachusetts Institute of Technology (MIT) by Sachs et al. (1993). According to Bose et al. (2013), filaments of viscous material, in solution form, are deposited, forming the extrusion based on the preconceived structure. The deposition of filaments occurs from layer to layer, at constant rate, under specific pressure.

The present work aimed to use threedimensional (3D) printing as a means of rapid prototyping for the production of exclusive embryological models. The general objective of the research was to produce embryological models, from a computer graphics design, using CAD tool and later obtaining by rapid prototyping - 3D printing, to facilitate the study in Embryology.

\section{MATERIAL AND METHODS}

The aspect of the human concept, in various stages of the embryonic development, was projected, in 3D, through the software SolidWorks, version 2015, with license available and provided by

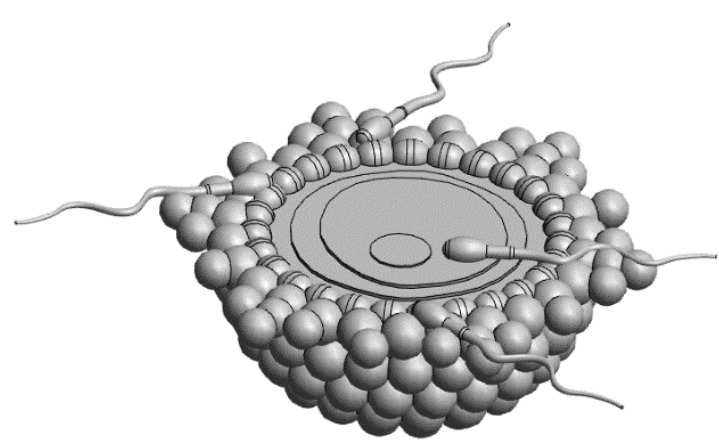

(A)
Centro Universitário FIPMoc (UNIFIPMoc), Montes Claros, MG. The models were designed in scale, in order to allow the comparison between models that represent different periods of ontogenic development.

It was used three-dimensional printer, model GTMax3D Core H4 and its respective software, Simplify3D. The polymer used as raw material for 3D printing was ABS (Acrylonitrile butadiene styrene), due to its low cost, ease of work in prototyping and mechanical resistance. Both the printer and the polymer were provided by UNIFIPMoc. In addition, didactic material related to the subject of Embryology and conception and formation of the human being, the book Embriologia clínica, by Moore for instance, was used. Finally, measuring instruments (pachymeter and micrometer) were necessary to gauge the measurements and proportions of the first manufactured parts.

\section{RESULTS}

Models were designed in 3D software that represent stages of human embryonic development, from fertilization to the third week of development (Figures 1, 2, 3 e 4). All the illustrated models were tested, being dropped of height of more than two meters, without presenting any compromise in their form or apparent damage to the material. It is possible to observe the richness of detail of the piece traditionally printed, representing the fertilization of the oocyte (Figure 1).

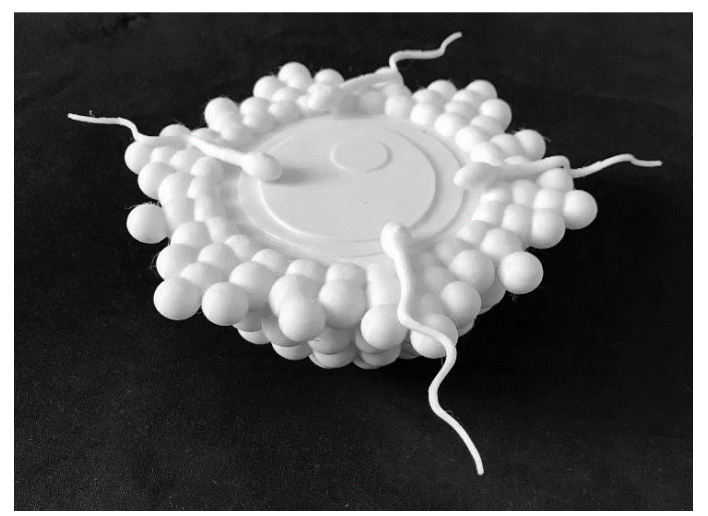

(B)

Figure 1. Representation of oocyte fertilization II. (A) 3D design created in SolidWorks; (B) Threedimensional model in ABS polymer. 


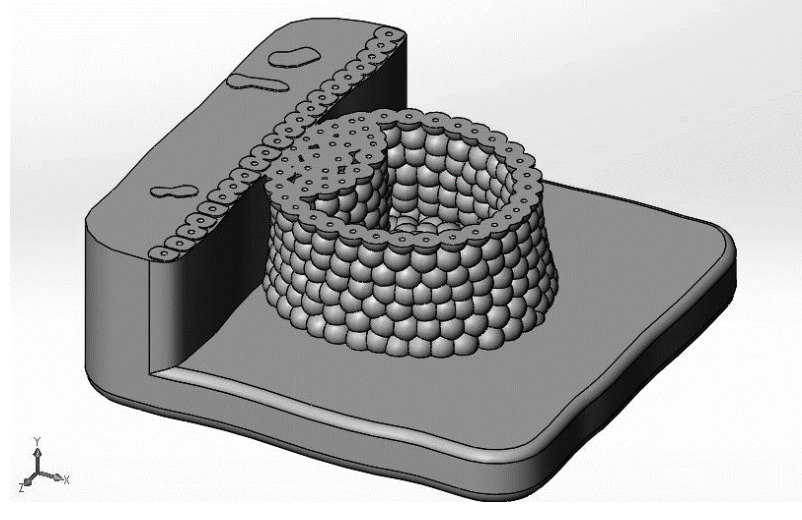

(A)

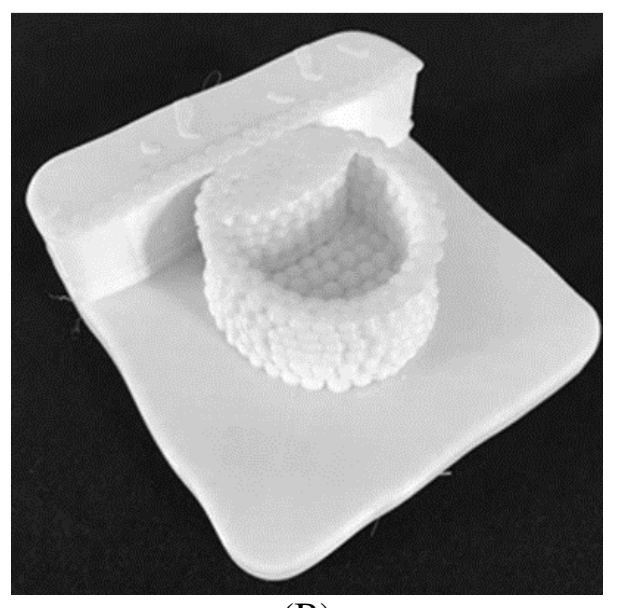

(B)

Figure 2. Blastocyst and beginning of the implantation of the concept in the uterine wall: (A) 3D drawing; (B) Print part from drawing.

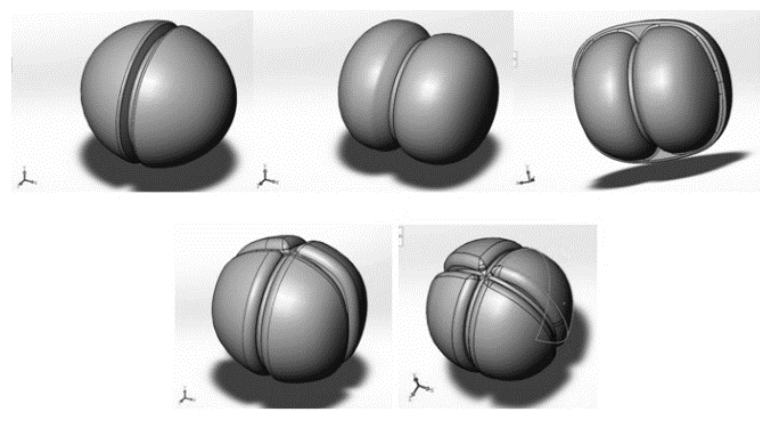

(A)

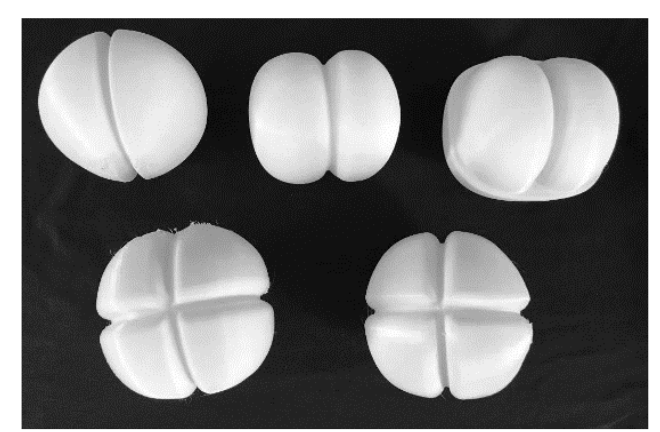

(B)

Figure 3. Representation of the morula phases of the embryo: (A) Project in the software; (B) Prototyped pieces from the computer project.

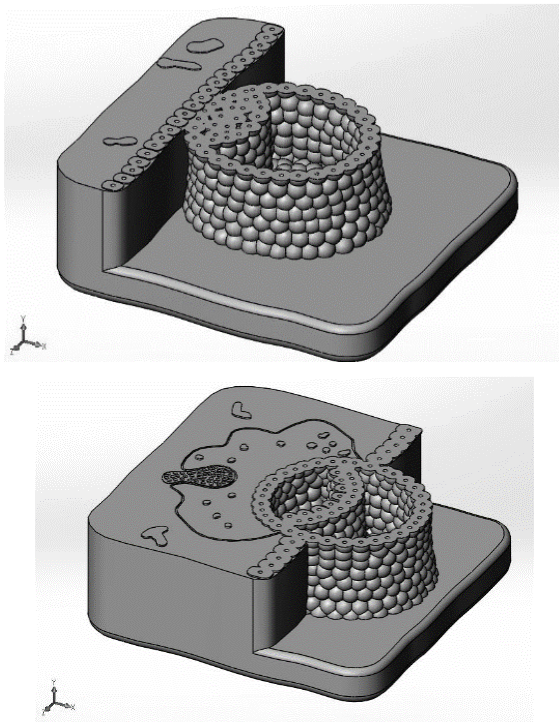

(A)

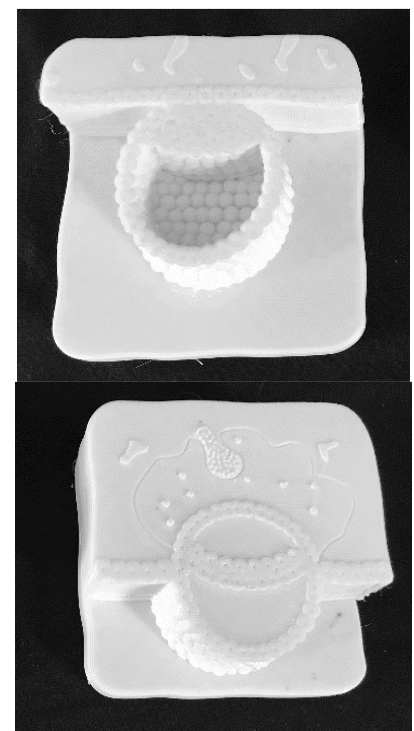

(B)

Figure 4. Representation of the second week of intrauterine development: (A) Design of embryological models; (B) Embryological models. 
The blastocyst, as well as the beginning of the implantation that occurs in the uterine wall, are presented in Figure 2. Figure 2a shows the 3dimensional representation created in the software, with its bottom gradient and coordinate system in the lower left corner. This visualization is provided in the software during design creation, in order to allow a better understanding of the size and depth of the designed object. Figure $2 b$, in white on a dark background, allows easy distinction of the presented details.

Using the computer program for $3 \mathrm{D}$ modeling allows for representation of complex geometries, as shown in the images for the projected steps. In addition, this program may be convenient to reproduce simple drawings in a standardized way or even use one drawing to modify it to create another, representative of a later stage of embryonic development. It is possible to observe what was said by the visualization of Figure 3 .

It is possible to arbitrate the color of the product, through the use of $\mathrm{ABS}$ raw material of different colors. The printed models are obtained in the white color (Figures 1, 2, 3 and 4). The white color was chosen because it facilitates the visualization of the geometry and its contours, besides allowing future coloration with the use of paints, in case the user deems necessary. The possibility of coloring the pieces is interesting to be able to give greater similarity to the images presented in the literature.

In addition to being possible to elaborate three-dimensional virtual representations that help in itself the understanding of the studied object, prototyping in $3 \mathrm{D}$ printing allows the use of a more human sense, by allowing the student to play the piece.

Computer-generated parts can be printed countless times, at low cost, allowing the production of standardized parts for study. It is considered low cost, since the base material, the polymer ABS, is quite accessible, in addition to being recyclable. What can make the process more expensive is the investment in a $3 \mathrm{D}$ printer.

\section{DISCUSSION}

This means of production allowed the elaboration of exclusive anatomical models, with low cost and ease of visual interpretation. The models of the embryonic period were designed in scale, such that it was possible to compare models representing distinct periods of ontogenic development.
Models developed by Freitas et al. (2008) show the degree of detail and the quantity of components that can be better visualized from a solid piece as object of study. However, some negative points of these handmade models are the time demanded in their conception and construction, besides the impossibility of standardization of the pieces, since they're handmade. When the handmade models are compared to the ones printed (Figure 4), it is possible to notice that both are rich in detail, however, the printed ones can be reproduced countless times with the exact same shape, geometry and detail, keeping a standard. The reproducibility of the printed models is important because it can represent less work in the preparation of the products, they can be changed based on a scale and proportion defined in the CAD software and, still, be manufactured in less time, multiple times.

According to Dryden and Vos (1996), it is possible to improve the teaching of something when students have the opportunity to involve more senses in the learning process. The interaction allowed by the embryological models goes beyond the vision of images, providing interaction between the piece and the student who uses it.

KIRNER (2011) comments that, as a disadvantage of the use of certain technologies, it is possible to highlight the need for someone with technical knowledge of the software used. This applies to the case of the present study, since it is necessary to know the SolidWorks software to design the pieces, besides knowing how to use a 3D printer. Specialized technical training is one option to reduce this disadvantage.

Although it seems distant from the knowledge that one has in health courses, as is the case of the target audience benefited by the product of the present work, the use of 3D modeling software can be quite intuitive. In the same way that you need to know how to model to create models in plaster or clay, among other materials, you must know how to use the appropriate computer program to design the virtual models.

The product of the present work contributes to the social inclusion of students with disabilities. For example, in the case of people who are blind or have low visual acuity. Since the parts obtained are three-dimensional, it is possible that they are studied by touch, rather than just the visualization of images. In addition, the dissemination of this practice can contribute to teaching methods so that other areas of science, in addition to embryology, can be worked in the same way. 


\section{CONCLUSIONS}

Since the models were designed in CAD (Computed Aided Design) 3D modeling software, it is feasible to print these, in layers, in polymer material, low cost and easy to handle. In this way, the purpose of improving the visualization, by the undergraduate students, of the stages of the embryonic development, will be reached.

The rapid prototyping technique, together with the CAD design of the components to be printed, allowed the detailed visualization of the desired models.
It is possible to contribute with a perspective of improvement of the understanding of the topic of embryology, for students of the health science major or related, through the visualization, in three dimensions, of models that are sometimes very expensive as physical pieces, or even nonexistent in the market. As a possibility of future work, which complements the study discussed here, one can test the acceptance of students to the models manufactured. In addition, it is possible to compare the proposed embryological models with others on the market. Finally, one can still test the mechanical properties of the models designed and manufactured.

RESUMO: Algumas áreas do conhecimento, geralmente, estão relacionadas a um alto grau de abstração envolvido no objeto estudado. Para o caso do estudo de embriologia, por exemplo, é recorrente a dificuldade de aprendizagem dos estudantes, por falta de recursos didáticos, que possam auxiliar no processo de interpretação das figuras apresentadas em literatura relacionada. Partindo da motivação de melhorar o ensino universitário, sobretudo na área de ciências biológicas, o presente trabalho objetiva representar, em 3 dimensões, etapas do desenvolvimento embriológico humano. Foi utilizado o software de modelagem 3D, SolidWorks, além de material didático relacionado ao assunto de embriologia, concepção e formação do ser humano, como livros, atlas e artigos científicos. Foram projetados, em software 3D, modelos que representem etapas do desenvolvimento embrionário humano. Esse meio de produção permitiu a elaboração de modelos anatômicos exclusivos, com baixo custo e facilidade de interpretação visual. Os modelos foram projetados em escala, de tal modo que foi possível a comparação entre modelos que representem períodos distintos do desenvolvimento ontogênico. Foi possível contribuir com melhora do entendimento do tema de embriologia, para estudantes da área da saúde, por meio da visualização, em três dimensões, de modelos que por vezes são muito caros como peças físicas, ou mesmo, inexistentes no mercado.

PALAVRAS-CHAVE: Embriologia. Impressão 3D. Ensino. Educação. Projeto assistido por computador.

\section{REFERENCES}

BOSE, S.; VAHABZADEH, S.; BANDYOPADHYAY, A. Bone tissue engineering using 3D printing.

Materials Today, v. 16, n. 12, p. 496-504, 2013. https://doi.org/10.1016/j.mattod.2013.11.017

DRYDEN, G.; VOS, J. Revolucionando o aprendizado. Makron Books, 1996.

FREITAS, L. A. M.; BARROSO, H. F. D.; RODRIGUES, H. G.; AVERSI-FERREIRA, T. A. Construção de modelos embriológicos com material reciclável para uso didático. Bioscience Journal, v. 24, n. 1, 2008.

GORNI, A. A. Introdução à prototipagem rápida e seus processos. Plástico Industrial, p. 230-239, 2001.

GRIMM, T. User's guide to rapid prototyping. Society of manufacturing engineers. Derbon, Michigan, USA, 2004.

KIRNER, C. Prototipagem rápida de aplicações interativas de realidade aumentada. Tendências e Técnicas em Realidade Virtual e Aumentada, v. 1, n. 1, p. 29-54, 2011.

MOORE, K. L.; Persaud, T. V. N. Embriologia Clínica. 8ª ed. Rio de Janeiro: Elsevier, 536 p. 2008. 
PEROTTA, B.; FIEDLER, P. T.; SANTOS, S. H. P. D.; HIROSE, T. E.; RODRIGUES, A. L. D. M.; OLIVEIRA, S. A. D.; SATO, M. H.; ÁVILA, H. S.; MORAES, T. C. D.; FERREIRA, F. D. F. Demonstração prática do desenvolvimento pulmonar humano. Arquivos da APADEC, Maringá, v. 8, n. supl 2, p. 14, 2004.

RODRIGUES, A. L. M.; FIEDLER, P. T.; SANTOS, S. H. P. D.; PEROTTA, B.; HIROSE, T. E.; OLIVEIRA, S. A. D.; SATO, M. H.; ÁVILA, H. S.; MORAES, T. C. D.; FERREIRA, F. D. F. I. Embriologia prática: uma lição diferente. Arquivos da APADEC, v. 8, n. supl 2, p. 11, 2004.

SACHS, E. M. et al. Three-dimensional printing techniques. U.S. Patent n. 5.204.055, 20 Abril. 1993.

SADLER, T. W. Langman: Embriologia Médica. 11ª edição. Editora Guanabara, 2010.

SOUZA, F. H. T.; SOUZA, E. L.; FALCAO, G. M.; MEDEIROS, L. N.; MONTEIRO, C. H.;

MASCARENHA, S. R. Impactando as aulas de Imunologia: apresentando o sistema imunológico com aulas práticas. Anais do IX Encontro de Extensão e X Encontro de Iniciação à Docência, 2007. 